\title{
Application of soil amendments and their effect in the growth of heliconia ${ }^{(1)}$
}

\author{
ARIADNA LINARES-GABRIEL ${ }^{(2)}$, CATALINO JORGE LÓPEZ-COLLADO(2)*, MARIO ALEJANDRO \\ HERNÁNDEZ-CHONTAL ${ }^{(2)}$, JOEL VELASCO-VELASCO(3), GUSTAVO LÓPEZ-ROMERO(2)
}

\begin{abstract}
The Heliconias have a great potential as a cut flower and for this reason an adequate management of the crop is important. The objective of this research was the application of soil amendments (Biol and superabsorbent polymers - SAP) and the analysis on their effect in the growth of Heliconia psittacorum cv. Tropica. An experiment was established using a completely randomized design with four treatments and five repetitions: SAP $\left(1 \mathrm{~g} \mathrm{plant}^{-1}\right)$, biol $\left(20 \mathrm{~mL}\right.$ plant $\left.{ }^{-1}\right)+\mathrm{SAP}\left(1 \mathrm{~g} \mathrm{plant}^{-1}\right)$, biol $\left(20 \mathrm{~mL}^{\mathrm{p}}\right.$ plant $\left.\mathrm{t}^{-1}\right)$ and one control (without application). A $20 \mathrm{~cm}$ rhizome was planted per pot and were evaluated the height of the plant, the number of leaves, the leaf area and the number of shoots were measured. The analysis of variance did not show statistical differences $(p \leq 0.05)$ between treatments for the variables of the height of the plant, the leaf area and the number of shoots, but statistical differences were found for the variable number of leaves $(p \leq 0.05)$, and the best treatments were Biol, SAP, and Biol + SAP. With the application of the biol and SAP amendments, it was not possible to increase the plant height, the leaf area and the number of Heliconia shoots. Regarding the application of SAP to the not found significant results in Heliconia, it is expected that treatments with SAP show a better effect in the dry season.
\end{abstract}

Keywords: tropical flowers, agroecological practices, biol, superabsorbent polymers.

\section{RESUMO}

\section{Alterações do solo e seu efeito no crescimento da heliconia}

As Heliconias têm um grande potencial como flor de corte sendo importante o manejo adequado da cultura. Neste sentido, objetivou-se aplicar alterações ao solo (Biol e Polímero superabsorvente - SAP) e analisar o seu efeito sobre o crescimento de Heliconia psittacorum cv. Tropica. Foi realizado experimento usando o delineamento experimental completamente ao acaso, com quatro tratamentos e cinco repetições: SAP $\left(1 \mathrm{~g} \mathrm{planta}^{-1}\right)$; Biol (planta de $\left.20 \mathrm{~mL}^{-1}\right)+\mathrm{SAP}\left(1 \mathrm{~g}_{\text {planta }}{ }^{-1}\right)$; Biol $\left(\right.$ planta de $\left.20 \mathrm{~mL}^{-1}\right)$ e um controle (sem aplicação). Foi cultivado um rizoma de $20 \mathrm{~cm}$ por vaso foram avaliados a altura da planta, número de folhas, área foliar e número de brotos. A análise de variância não mostrou nenhuma diferença estatística $(p \leq 0,05)$ entre os tratamentos para as variáveis altura de planta, área foliar e número de brotos; porém, obteve-se diferença significativa para a variável número de folhas $\mathrm{p} \leq$ 0,05). Os melhores tratamentos foram Biol, SAP e Biol + SAP. Com a aplicação das alterações de biol e SAP, não foi possível aumentar a altura de plantas, a área foliar e o número de brotações de heliconia. Em relação à aplicação de SAP aos resultados não significativos em Heliconia, espera-se que tratamentos com SAP tenham um efeito melhor na estação seca.

Palavras-chave: flores tropicais, práticas agroecológicas, biol, polímeros superabsorventes.

\section{INTRODUCTION}

Sustainable agriculture tries to find alternatives to conventional practices that are economically feasible with less incidence of environmental damage; a clear example is reflected in the use of organic amendments (HUE and SILVA, 2000). Organic amendments are used in the recovery of soils and come from various sources, mainly agriculture such as livestock manure (either solid or processed in anaerobic digesters), but also crop residues. The effects of the amendments can be direct, through the properties of the amendments (eg. nutrients) or indirect, modifying the physical, biological, and chemical properties of the soil (LARNEY and ANGERS, 2012). This study considers the application of 'biol' bioferments which results from anaerobic digestion of organic materials and contains minerals that can be used in crop fertilization (FERRER et al., 2009; KHALID et al., 2011), since it promotes performance and reduces the loss of nutrients (WALSH et al., 2012), having environmental benefits (LIJÓ et al., 2014). With these characteristics, it can be used as a complement to chemical fertilization, allowing replacing the dependence of external inputs (BOJÓRQUEZ et al., 2010).

Another amendment used in agricultural practices is the "hydrogel" (superabsorbent polymers SAP), it has been used to improve the survival and establishment of seedlings, particularly in dry environments. However, its water stress effect is little known (GASGUE, 2006; MUDHANGANYI et al., 2018), these polymers have the capacity to absorb from 400 to $1500 \mathrm{~g}$ of water per dry gram (KOUPAI

DOI: http://dx.doi.org/10.14295/oh.v24i3.1252

(1) Received in 06/07/2018 and accepted in 27/08/2018

${ }^{(2)}$ Colegio de Postgraduados Campus Veracruz, Manlio Fabio Altamirano-Veracruz, México. *Corresponding author: cjlc2000@hotmail.com

${ }^{(3)}$ Colegio de Postgraduados Campus Córdoba, Amatlán de los Reyes-Veracruz, México.

Licensed by CC BY 4.0 
et al., 2008), retain and leave it available for the growth of plants (AKHTER et al., 2004) taking advantage of rainwater or spacing irrigation frequencies (GASGUE, 2006; KOUPAI et al., 2008).

The use of these amendments can be used in various crops, since they mostly need nutrients and water resources. In this sense our research aims to use these agricultural amendments in the cultivation of Heliconia (Heliconia psittacorum cv. Tropica). Heliconias are beautiful tropical flowers that help increase the profits of the cut flowers industry worldwide, the durability of the inflorescence and the bright colors support the commercialization in the international market (COSTA et al., 2009). This ornamental contains highly diversified plants and up to 220 species have been reported from northern Mexico to southern Brazil commonly used in gardens and as cut flowers (PEREIRA et al., 2016). Heliconia psittacorum L. covers these commercial characteristics with a high economic potential due to its diversity of shapes, colors and its long vase life (BAÑUELOS-HERNANDEZ et al., 2016). However, they may be vulnerable in the productive phase (MACHADO et al., 2011), generally, Heliconias are susceptible to the attack of pests, diseases (SOSA RODRÍGUEZ, 2013), water stress conditions (they may need an irrigation dose of 2 to $5 \mathrm{~L} \mathrm{~m}^{2}$ day $^{-1}$ ), according to the state of the crop and time of year (DÍAZ et al., 2008), it also requires high rates of macro nutrients, especially nitrogen (CASTRO et al., 2015).

Considering the qualities of the mentioned amendments, 'biol' and 'SAP' as well as the nutritional and hydric needs of the Heliconias, the objective of this study was to apply amendments to the soil (Biol and SAP) and analyze their effect on the growth of Heliconia (Heliconia psittacorum cv. Tropica), with the intention of generating useful information on the efficient use of nutrients and water in the production of ornamental plants, with economic and operational impact more appropriate for producers.

\section{MATERIALS AND METHODS}

\section{Location}

The investigation was carried out from May to October 2014 at located on the Tepetates land, municipality of Manlio Fabio Altamirano $19.27^{\circ} \mathrm{NL}, 96.27^{\circ} \mathrm{WL}$ and 36 meters above sea level. It presents a subhumid warm climate of type $\mathrm{Aw}_{1}$ (GARCÍA, 1988).

\section{Soil characteristics}

The soil was collected and according to the analyzes performed showed the following characteristics: $\mathrm{pH} 7.57$, electrical conductivity $1.04 \mathrm{dS} \mathrm{m} \mathrm{m}^{-1}$, organic matter $7.73 \%$, total nitrogen $0.33 \%$, inorganic nitrogen $98.3 \mathrm{mg} \mathrm{kg}^{-1}$, phosphorus $33.81 \mathrm{mg} \mathrm{kg}^{-1}$, potassium $684 \mathrm{mg} \mathrm{kg}^{-1}$, cation

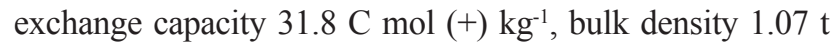
$\mathrm{m}^{-3}$, field capacity $28.53 \%$, saturation point $54.11 \%$, sandyloam texture.

\section{Experimental design and treatments}

A completely randomized block design was used with four treatments and five replications: 1) SAP, 2) Biol + SAP, 3) Biol and 4) control (without application).

\section{Fertilizer characteristics}

The biol was elaborated in a batch or stationary biodigestor, using a 20L hermetic container (GOMERO, 2005), the inputs used were the following: water $58 \%$, manure $22 \%$, soybean paste $10 \%$, and molasses $10 \%$. The fermentation process was carried out for 60 days and according to the analyzes performed showed the following characteristics: $\mathrm{pH} 8.25$, total nitrogen $0.33 \%$, inorganic nitrogen $1724 \mathrm{mg} \mathrm{L}^{-1}$, phosphorus $1646 \mathrm{mg}$ $\mathrm{L}^{-1}$, potassium $710 \mathrm{mg} \mathrm{L}^{-1}$.

\section{Crop management}

The sowing was carried out in nursery conditions using pots with a size of $22 \times 20 \times 17 \mathrm{~cm}$ and soil with an amount of $4 \mathrm{~kg}$ per pot. The rhizomes were harvested and the pseudostem was cut to leave it at a length of $20 \mathrm{~cm}$; very long and dead roots were removed. Finally, it was immersed in a captan solution $\left(1 \mathrm{~g} \mathrm{~L}^{-1}\right)$ in the basal part and where the cut was made. In each pot, a rhizome was placed in the center at a depth of $5 \mathrm{~cm}$. Subsequently, irrigation was carried out at planting. $20 \mathrm{~mL}$ of biol was applied at $50 \% \mathrm{v} \mathrm{v}^{-1}$ (volume per volume) of water per plant, making three applications; to planting and later at 15 and 30 days. The commercial product of superabsorbent polymers (water silos ${ }^{\circledR}$ ) was used, and $1 \mathrm{~g}$ was applied at the time of planting buried at a distance of 15 $\mathrm{cm}$ and $10 \mathrm{~cm}$ deep from the plant.

\section{Evaluated variables}

The plant height was measured using a graduated rule, measuring from the base of the stem to the maximum length of the leaves, collecting them upwards, the measurements were at 30, 60, 90, and 150 days after planting (DAP), and at 150 DAP the number of shoots was counted, number of leaves and the leaf area was determined, measuring the length and width of the highest leaf and multiplied by 0.74 used by Farias et al. (2013).

\section{Statistical analysis}

For the analysis of variance, square root transformations were made to the original data of the variables number of leaves and number of shoots. Tukey analysis of variance and comparison of means $(p \leq 0.05)$ was performed using the statistical package Statistical Analysis System (SAS, 2014).

\section{RESULTS AND DISCUSSION}

\section{Plant height}

According to the analysis of variance and the means test with Tukey, no significant statistical differences were found $(p \leq 0.05)$ between treatments for the plant height variable in the samples taken at 30,60,90 and 150 days (Tables 1 and 2). One of the factors by which it is considered that the response in height coincided in all the treatments was due to the presence of rains that did not allow the SAP and the 'biol' to show their effect, since according to the meteorological station of the Colegio de Postgraduados, Campus Veracruz, reported an average of $15 \mathrm{~mm} \mathrm{~m}^{2}$ per day. 
Table 1. Analysis of variances for the variables evaluated in Heliconia (Heliconia psittacorum cv. Tropica)

\begin{tabular}{|c|c|c|}
\hline Variables & Levels of significance & Coefficient of variation \\
\hline Plant height 30 DAP & $0.9518^{*}$ & 28.575 \\
\hline Plant height 60 DAP & 0.9446 & 16.07244 \\
\hline Plant height 90 DAP & 0.8547 & 19.45874 \\
\hline Plant height 150 DAP & 0.4955 & 18.73442 \\
\hline Number of shoots 150 DAP & 0.2073 & 25.89617 \\
\hline Number of leaves 150 DAP & 0.0522 & 15.61652 \\
\hline Leafarea 150 DAP & 0.2395 & 17.26055 \\
\hline
\end{tabular}

${ }^{*} p \geq 0.05$, not significant

It is considered that the Heliconias need an irrigation dose of on average from 2 to $5 \mathrm{~L} \mathrm{~m}^{2}$ day $^{-1}$, depending on the state of the crop and time of year (DÍAZ et al., 2008). Temperatures during the study were favorable as oscillated on average 27.7 ${ }^{\circ} \mathrm{C}$, as the ideal temperature varies between $18{ }^{\circ} \mathrm{C}$ and $34^{\circ} \mathrm{C}$ for growing of these species (JEREZ, 2007), this favored a similar behavior in height of the plant for treatments, in other words, both the substrate and environmental conditions affect or favor the formation of heliconia seedlings (BECKMANNCAVALCANTE et al., 2011).

Table 2. Comparison of means for the variable height of the plant in Heliconia (Heliconia psittacorum cv. Tropica)

\begin{tabular}{|c|c|c|c|c|}
\hline Treatments & $\mathbf{3 0} \mathbf{D A P}^{\mathbf{z}}$ & $\mathbf{6 0} \mathbf{D A P}$ & $\mathbf{9 0} \mathbf{D A P}$ & $\mathbf{1 5 0}$ DAP \\
\hline SAP & $29.88^{\mathrm{a}}$ & $39.75^{\mathrm{a}}$ & $59^{\mathrm{a}}$ & $65.25^{\mathrm{a}}$ \\
\hline Biol + SAP & $39.5^{\mathrm{a}}$ & $43.25^{\mathrm{a}}$ & $56.75^{\mathrm{a}}$ & $65.5^{\mathrm{a}}$ \\
\hline Biol & $43.38^{\mathrm{a}}$ & $44.5^{\mathrm{a}}$ & $59^{\mathrm{a}}$ & $68.25^{\mathrm{a}}$ \\
\hline Control & $37.5^{\mathrm{a}}$ & $46^{\mathrm{a}}$ & $58.75^{\mathrm{a}}$ & $68.25^{\mathrm{a}}$ \\
\hline HSD $^{\mathrm{x}}$ & 24.758 & 15.954 & 25.074 & 27.63 \\
\hline
\end{tabular}

* Means with the same letter within each column do not differ statistically (Tukey, $p \leq 0.05$ ).

${ }^{z}$ Days after planting.

${ }^{\mathrm{x}}$ Honestly significant difference

On the other hand, when there are drought environments, Akhter et al. (2004) it is mentioned that the addition of hydrogel (SAP) can improve water storage to increase plant growth, which is why the heights in this evaluation were not differentiated.

Likewise, Carvalho et al. (2012) evaluated height of Heliconia psittacorum $x$ H. spathocircinata, cv. Golden Torch, with organic fertilization of manure. Obtained heights at 90 and 120 days of $13.81 \mathrm{~cm}$ and $19.09 \mathrm{~cm}$ respectively, values lower than those found in this evaluation. Another factor that influenced was the low concentrations of N-P-K that the biol contains, since the effect is slower because it is an organic fertilizer, which is why some authors recommend applications of 46, 50 and $150 \mathrm{~kg} \mathrm{ha}^{-1}$ of N-P-K (SOSA RODRÍGUEZ, 2013). Although what is sought is to guide the use of organic amendments, in some cases the synthetic can be combined with the organic. For example Farias et al. (2013) evaluated some agronomic variables in Heliconia sp., and mentioned that the organo-mineral fertilization provided a significant increase, contributing to a shorter flowering interval, in comparison with the organic fertilizers and the control. Therefore it is advisable to combine both fertilizers, since chemical fertilizers add nutrients (nitrogen, phosphorus, potassium, micronutrients), but not organic matter. On the contrary, organic amendments add nutrients as well as organic matter, offering many more opportunities to improve the physical, chemical and biological properties 
of soil, important for the success of soil recovery initiatives (LARNEY and ANGERS, 2012).

\section{Number of shoots}

For the variable number of shoots, no significant statistical differences were found $(p \leq 0.05)$ among the treatments (Table 1), an average of three shoots was obtained up to 150 days (Table 3 ).

Organic amendments favor the properties of the soil in numerous and variable ways, the effects can be direct, through the intrinsic properties of the organic amendments, or indirect, modifying the physical, biological and chemical properties of the soil (LARNEY and ANGERS, 2012). These results coincide with Carvalho et al. (2012) who obtained at 150 days in Heliconia psittacorum $x$ H. spathocircinata, cv. Golden Torch, two to three shoots in the control treatments, manure, N-P-K and the combination of both (N-P-K + manure) in field conditions. The amendments may be favorable for the growth of Heliconias and that its effect is also assimilated with the application of mineral fertilizers as mentioned in the previous study.

Table 3. Comparison of means for the variables number of shoots, leaf area, and number of leaves in plants Heliconia (Heliconia psittacorum cv. Tropica) at $150 \mathrm{DAP}^{\mathrm{z}}$

\begin{tabular}{|c|c|c|c|c|c|}
\hline Treatments & Number of shoots & Treatments & Leaf area $\mathbf{( c m}^{\mathbf{2}}$ & Treatments & Number of leaves $^{\mathbf{1}}$ \\
\hline Biol + SAP & $3.80^{\mathrm{a}^{*}}$ & Biol & $490^{\mathrm{a}^{*}}$ & Biol + SAP & $15^{\mathrm{a}^{*}}$ \\
\hline Control & $3.40^{\mathrm{a}}$ & Biol + SAP & $448^{\mathrm{a}}$ & Control & $13.40^{\mathrm{ab}}$ \\
\hline Biol & $3.20^{\mathrm{a}}$ & SAP & $424^{\mathrm{a}}$ & SAP & $12^{\mathrm{ab}}$ \\
\hline SAP & $2.60^{\mathrm{a}}$ & Control & $388^{\mathrm{a}}$ & Biol & $11.20^{\mathrm{b}}$ \\
\hline HSD $^{\mathrm{x}}$ & 1.5803 & HSD & 0.0142 & HSD & 3.7826 \\
\hline
\end{tabular}

*Means with the same letter within each column do not differ statistically (Tukey, $p \leq 0.05$ ).

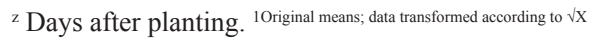

${ }^{\mathrm{x}}$ Honestly significant difference

During the evaluation, the first shoots were observed 30 days after sowing, these results differ from Carvalho et al. (2012), who observed the first shoots 55 days after planting in Heliconia psittacorum $x$ H. spathocircinata, cv. Golden Torch. Ibiapaba et al. (2000) obtained the first shoots of Sassy and Andromeda heliconias varieties at 2030 days after planting. The above can influence the tillering potential, since it can be determined by the genotype, soil, fertilization and climatic conditions of each region. In this sense, Criley et al. (2001) consider that the number of tillers of heliconias per plant is directly related to the production of stems of the flowers, in addition to the reduction in the number of tillers is related to the competition between plants.

In the same way, it matches authors like Akhter et al. (2004), that the addition of hydrogel increases the retention of moisture to field capacity linearly in loamy sandy soils; used in this study, which is why no differences were found in the number of side shoots, having the same behavior, coupled with the presence of rains as mentioned above. It is suggested that hydrogels can be used to extend sowing beyond the rainy season to include dry months (MUDHANGANYI et al., 2018).

\section{Leaf area}

According to the analysis of variance and the means test with Tukey, no significant statistical differences were found $(p \leq 0.05)$ between the treatments for the variable leaf area at 150 days (Table 1).
Hydrogel amendments have been used to improve the survival and establishment of seedlings, particularly in dry environments (MUDHANGANYI et al., 2018). So the effect of the SAP did not show its effect again, as it had already been mentioned the sowing period was from May to October, where there were frequent rains, and temperature was another factor that favored the growth of the plant. On the contrary, if high amounts of water are required in times of drought, the level of irrigation from $75 \%$ to $150 \%$ of the evaporation measured in Class A (ECA) can provide better results for the foliar area in the culture of Heliconia psittacorum cv. Golden Torch in pot and protected environment (SILVA et al., 2018).

The leaf area can be negatively reflected in the development of the plant, taking into account that the reduction is involved in the process of photosynthesis, depending on the interception of light energy and its conversion into chemical energy (ALBUQUERQUE et al., 2010; ALBUQUERQUE et al., 2014). Therefore, it is important to increase the area of the leaf since it can promote a more efficient photosynthetic rate per unit of leaf area that contributes to the increase in the synthesis of minerals (FARIAS et al., 2013).

The null response of the treatments on foliar area could have been influenced by the lack of nutrients facilitated by the biol, which coincides with what was found by Castro et al. (2007) and Albuquerque et al. (2010) in the cultivation of Heliconias. However, it differs from Ndubuaku et al. (2014), since when applying biol based on rice husks in 
Okra plants, they observed different values in divided doses of $300 \mathrm{ml} / \mathrm{bag}$ before sowing and one month after emergence, a higher dose of biol than the one used in this study that was $60 \mathrm{ml}$ during the five months. Another influence on the effect of leaf area is related to the nutrient content of the bioferment and therefore the inputs used to obtain it, this causes a variation in the response in crops of Heliconias (BOJÓRQUEZ et al., 2010).

Farias et al. (2013) consider necessary to complement the chemical fertilization with the biofertilizer since the latter contributes only with $40 \%$ of the total fertilization required. So it is suggested to consider organic fertilization as a complement to chemical fertilization in heliconias. For example, Albuquerque et al. (2014) showed that the application of sodium silicate was better to influence the growth of Heliconia psittacorum cv. Golden Torch, the silicon content in the leaf increased with doses on the rise of calcium silicate application.

In this sense, deficiency symptoms can be chlorosis usually due to nitrogen deficiency, mild chlorosis due to phosphorus and sulfur deficiency, dark green leaves and potassium deficiency necrosis, marginal chlorosis and magnesium deficiency necrosis that is why deficiencies in $\mathrm{N}$ and $\mathrm{P}$ affect the leaf area (CASTRO et al., 2015).

Another factor that directly affects the foliar area is the direct exposure to the sun, in the study the plants were exposed to $50 \%$ of the sun, which is why the conditions were favorable for all treatments, for example $50 \%$ of the shading provided is effective to achieve the desired establishment and growth of Heliconia bihai cv. Humilis and Heliconia psittacorum cv. Golden Torch, grown in pots, which indicates that the two species have different morphological mechanisms for adaptation in shaded environments. On the other hand, plants grown in full sun ( $0 \%$ shade) show lower growth (height and leaf area) and lower chlorophyll content (SOUZA et al., 2016).

\section{Number of leaves}

For the variable number of leaves, significant differences were found $(p \leq 0.05)$ between treatments (Table 1), and according to the means test with Tukey $(p \leq 0.05)$, the treatment of the application of 'biol' + SAP showed better behavior in comparison with the treatment of the application of 'biol', as shown in Table 3. The number of leaves was accounted for bush (tiller), according to the number of lateral shoots per treatment, as mentioned above an average of three shoots was obtained, that is to say that for the treatments 'biol' + SAP five leaves were obtained, for the control and SAP four leaves were obtained, and for the treatment of 'biol' only three leaves were obtained.

Authors like Albuquerque et al. (2010) did not have significant differences between treatments of organic and mineral fertilization in Heliconia psittacorum cv. Golden Torch, however they obtained about four leaves per stem. They mention that the leaves are responsible for photosynthesis and that they have a direct importance in the development of the shrub, stem and bracts of flower stems.
In another work done in Brazil, the number of leaves in pendular species varies from four to six in $H$. chartaceae, H. collinsiana, H. magnifica, H. pendula, H. platystachys, $H$. pogonantha and $H$. rauliniana (LOGES et al., 2016).

The results are similar to those of Carvalho et al. (2012), they obtained 150 days of evaluation in Heliconia psittacorum $x H$. spathocircinata, cv. Golden Torch, between four and five leaves in each of its organic and mineral treatments. In this sense, the addition of organic fertilizers is essential for fertility, since its slow action constantly supplies the gradual organic compounds (MALAVOLTA et al., 2002).

\section{CONCLUSIONS}

With the application of the biol and SAP amendments, it was not possible to increase the plant height, the leaf area and the number of Heliconia shoots. However, a significant increase in the number of leaves can be achieved. According to the results found, the application of chemical fertilizer can be considered as a complement to the application of biol, and in this way satisfies the nutrient requirements of the crop. Regarding the application of SAP to the not found significant results in Heliconia, it is expected that treatments with SAP show a better effect in the dry season.

\section{AUTHORS CONTRIBUTIONS}

A.L.G. ${ }^{10000-0002-3825-5450}$ : contributed to the research design, fieldwork and writing of paper. C.J.L.C. (0000 $00033182 \quad 6027$ : contributed to the research design. M.A.H.C. D0000-0002-9711-7971: contributed to the research design, fieldwork and writing of paper. J.V.V. (D0000 00033854 9376: contributed to the paper writing. G.L.R. D0000-0003-1831-0368: contributed to the paper writing.

\section{REFERENCES}

AKHTER, J.; MAHMOOD, K.; MALIK, K.; MARDAN, A.; AHMAD, M.; IQBAL, M. Effects of hydrogel amendment on water storage of sandy loam and loam soils and seedling growth of barley, wheat and chickpea. Plant Soil and Environment, v.50, n.10, p.463-469, 2004. DOI: 10.17221/4059-PSE

ALBUQUERQUE A.W.; DOS SANTOS J.M.; A.P., D.F. Produtividade e qualidade pós-colheita de Helicônia Golden Torch submetida a fontes e doses de silício. Revista Brasileira de Engenharia Agrícola e Ambiental, v.18, n.2, p.173-179, 2014. DOI: 10.1590/S141543662014000200007

ALBUQUERQUE, A.W.; ROCHA, E.S.; DA COSTA, J.P.V.; FARIAS, A.P.; BASTOS, A.L. Produção de Heliconia Golden Torch influenciada pela adubação mineral e orgânica. Revista Brasileira de Engenharia Agricola e Ambiental, v.14, n.10, p.1052-1058, 2010. DOI: http:// dx.doi.org/10.1590/S1415-43662010001000005 
BAÑUELOS-HERNANDEZ, K.P. K.P.; GARCIA-NAVA, J.R.; LEYVA-OVALLE, O.R.; PENA-VALDIVIA, C.B.; YBARRA-MONCADA, M.C. Flowering stem storage of Heliconia psittacorum L. f. cv. Tropica. Postharvest Biology and Technology, v.112, p.159-169, 2016. DOI: 10.1016/j.postharvbio.2015.10.006

BECKMANN-CAVALCANTE, M.Z.; AMARAL, G.C.; SILVA, A.A.; CAVALCANTE, Í.H.L.; LIMA, M.P.D. Alternative substrates for production of Heliconia psittacorum L. seedlings under shade and open field conditions. African Journal of Biotechnology, v.10, n.68, p.1527215277, 2011. DOI: http://dx.doi.org/10.5897/AJB11.1028

BOJÓRQUEZ, A.D.A.; GUTIÉRREZ, C.G.; BÁEZ, J.R.C.; SÁNCHEZ, M.Á.A.; MONTOYA, L.G.; PÉREZ, E.N. Biofertilizantes en el desarrollo agrícola de México. Ra Ximhai: revista científica de sociedad, cultura y desarrollo sostenible, v.6, n.1, p.51-56, 2010. http://www. redalyc.org/articulo.oa? $\mathrm{id}=46112896007$

CARVALHO, J.S.B.; MARTINS, J.D.L.; ULISSES, C.; SILVA, W.L. Adubação orgânica, mineral e organomineral e sua influencia no crescimento da helicônia em garanhuns-PE. Horticultura Brasileira, v.30, p.579-583, 2012. DOI: http://dx.doi.org/10.1590/S0102-05362012000400003

CASTRO, A.C.R.; LOGES, V.; DA COSTA, A.S.; DE CASTRO, M.F.A.; DE ARAGÃO, F.A.S.; WILLADINO, L.G. Hastes florais de Helicônia sob deficiência de macronutrientes. Pesquisa Agropecuaria Brasileira, v.42, n.9, p.1299-1306, 2007. DOI: http://dx.doi.org/10.1590/ S0100-204X2007000900012.

CASTRO, A.C.R.; WILLADINO, L.G.; LOGES, V.; DE CASTRO, M.F.A.; DE ARAGÃO, F.A.S. Macronutrients deficiency in Heliconia psittacorum x Heliconia spathocircinata 'Golden Torch'. Revista Ciência Agronômica, v.46, p.258-265, 2015. DOI: 10.5935/1806-6690.20150005

COSTA, A.S.; LOGES, V.; GUIMARÃES, W.N.R.; CASTRO, A.C.R.; NOGUEIRA, L.C. Heliconia genotypes under partial shade: II. Evaluation of flowering stems. Acta Horticulturae, v.813, p.171-176, 2009. DOI: 10.17660/ ActaHortic.2009.813.21

CRILEY, R.A.; MACIEL, N.; FU, Z.; UCHIDA, J. Productivity of three heliconia hybrids. Bulletin of Heliconia Society Intl, v.10, n.3, p.1-3, 2001.

DÍAZ, M.; MANSITO, P.; PÉREZ-DÍAZ, M.; CID, M.; SOCORRO, A. Efecto de las dosis de riego, aplicadas según demanda, en cultivo sin suelo de heliconia. Actas de Horticultura, v.52, p.300-304, 2008.
FARIAS, A.P.; DE ALBUQUERQUE, A.W.; FILHO, G.M.; REIS, L.S. Produtividade da Heliconia psittacorum x Heliconia pathocircinada cv. Golden Torch sob diferentes fontes de adubação orgânica. Revista Brasileira de Engenharia Agricola e Ambiental, v.17, n.7, p.713-720, 2013. DOI: http://dx.doi.org/10.1590/S141543662013000700004 .

FERRER, I.; GAMIZ, M.; ALMEIDA, M.; RUIZ, A. Pilot project of biogas production from pig manure and urine mixture at ambient temperature in Ventanilla (Lima, Peru). Waste Management, v.29, n.1, p.168-173, 2009. DOI: https://doi.org/10.1016/j.wasman.2008.02.014

GARCÍA, E. Modificaciones al sistema de classificación climática de Köppen. México: Universidad Nacional Autónoma de México, 1988. 90p.

GASGUE, B. Los hidrogeles poliméricos como potenciales reservorios de agua y su aplicación en la germinación de semillas de tomate en diferentes tipos de suelos. Revista Iberoamericana de Polímeros, v.7, p.199-210, 2006.

GOMERO, O.L. Improving organic fertilizers. Low External Input and Sustainable Agriculture, v.21, n.1, p.14-15, 2005.

HUE, N.; SILVA, J. Organic soil amendments for sustainable agriculture: organic sources of nitrogen, phosphorus, and potassium. In: SILVA, J.A.; UCHIDA, R. Plant Nutrient Management in Hawaii's Soils, Approaches for Tropical and Subtropical Agriculture. Manoa: University of Hawaii, 2000. p.33-144.

IBIAPABA, M.V.B.; LUZ, J.M.Q.; INNECCO, R. Evaluation of spacing in Heliconia psittacorum L. cv. Sassy and Andromeda. Ciência e Agrotecnologia, v.24, n.1, p.181-186, 2000.

JEREZ, E. El cultivo de las Heliconias. Cultivos tropicales, v.28, n.1, 2007.

KHALID, A.; ARSHAD, M.; ANJUM, M.; MAHMOOD, T.; DAWSON, L. The anaerobic digestion of solid organic waste. Waste management, v.31, n.8, p.1737-1744, 2011. DOI: https://doi.org/10.1016/j.wasman.2011.03.021

KOUPAI, J.A.; ESLAMIAN, S.S.; KAZEMI, J.A. Enhancing the available water content in unsaturated soil zone using hydrogel, to improve plant growth indices. Ecohydrology \& Hydrobiology, v.8, n.1, p.67-75, 2008. DOI: https://doi.org/10.2478/v10104-009-0005-0

LARNEY, F.J.; ANGERS, D.A. The role of organic amendments in soil reclamation: A review. Canadian Journal of Soil Science, v.92, n.1, p.19-38, 2012. DOI: https://doi. org/10.4141/cjss2010-064 
LIJÓ, L.; GONZÁLEZ-GARCÍA, S.; BACENETTI, J.; FIALA, M.; FEIJOO, G.; LEMA, J.M.; MOREIRA, M.T. Life Cycle Assessment of electricity production in Italy from anaerobic co-digestion of pig slurry and energy crops. Renewable Energy, v.68, p.625-635, 2014. DOI: https:// doi.org/10.1016/j.renene.2014.03.005

LOGES, V.; CASTRO, C.E.F.; CASTRO, A.C.R.; GONÇALVES, C. Characteristics of pendent heliconia for use in landscape and as cut flower. Ornamental Horticulture, v.22, n.3, p.287-295, 2016. DOI: 10.14295/oh.v22i3.942

MACHADO NETO, A.DE S.; JASMIN, J.M.; PONCIANO, N.J. Economia na produção de helicônias no Estado do Rio de Janeiro Economy in helicônias production in Rio de Janeiro State. Ciência Rural, v.41, n.10, p.1858-1863, 2011. https://dialnet.unirioja.es/servlet/articulo? codigo $=5672927$

MAlavolta, E.; GOMES, P.F.; AlCARDE, J.C. Adubos e adubações. São Paulo: Nobel, 2002. 200p.

MUDHANGANYI, A.; NDAGURWA, H.G.T.; MARAVANYIKA, C.; MWASE, R. The influence of hydrogel soil amendment on the survival and growth of newly transplanted Pinus patula seedlings. Journal of Forestry Research, v.29, n.1, p.103-109. DOI: https://doi.org/10.1007/s11676017-0428-1.

NDUBUAKU, U.; IMEGWU, C.; NDUBUAKU, N. Nutrient compositions of liquid and solid fractions of organic waste fermentation and the influence on growth and yield of okra. International Journal of Development Research, v.4, n.9, p.1909-1914, 2014.
PEREIRA, F.R.A.; MORAES, R.M.; MARTINS, L.S.S.; MONTARROYOS, A.V.V.; LOGES, V. Genetic diversity and morphological characterization of half-sib families of Heliconia bihai L., H. chartacea Lane ex Barreiros, and $H$. wagneriana Peterson. Genetics and Molecular Research, v.15, n.2, p.9, 2016. DOI: 10.4238/gmr.15028003

SAS. Statistical Analysis System. SOFTWARE. Cary: SAS Analytics, 2014.

SILVA, A.A.; BECKMANN-CAVALCANTE, M.Z.; MOREIRA DA SILVA, E.; ETTORE PAVAN, B.; TEIXEIRA LOBO, J.; NERES DA SILVA, M.D.L. Heliconia cv. Golden Torch cultivated under different irrigation depths in protected environment. Ornamental Horticulture, v.24, n.1, p.7, 2018-04-26 2018. DOI: https://doi.org/10.14295/ oh.v24i1.1127

SOSA RODRÍGUEZ, F.M. Cultivo del género Heliconia. Cultivos Tropicales, v.34, n.1, p.24-32, 2013.

SOUZA, R.R.; CAVALCANTE, M.Z.B.; SILVA, E.M.; AMARAL, G.C.; BRITO, L.P.S.; AVELINO, R.C. Growth and changes on morphology and physiology of heliconias according to different shading environments. Comunicata Scientiae, v.7, n.2, p.214-222, 2016. DOI: https://doi. org/10.14295/cs.v7i2.884

WALSH，J.J.; JONES，D.L.; EDWARDS $\square$ JONES，G.; WILLIAMS, A.P. Replacing inorganic fertilizer with anaerobic digestate may maintain agricultural productivity at less environmental cost. Journal of Plant Nutrition and Soil Science, v.175, n.6, p.840-845, 2012. DOI: https://doi. org/10.1002/jpln.201200214 